\title{
Characterization of ambient volatile organic compounds and their sources in Beijing, before, during, and after Asia-Pacific Economic Cooperation China 2014
}

\author{
J. Li, S. D. Xie, L. M. Zeng, L. Y. Li, Y. Q. Li, and R. R. Wu \\ College of Environmental Science and Engineering, State Key Joint Laboratory of Environmental Simulation and Pollution \\ Control, Peking University, Beijing, China
}

Correspondence to: S. D. Xie (sdxie@ @ku.edu.cn)

Received: 4 March 2015 - Published in Atmos. Chem. Phys. Discuss.: 29 April 2015

Revised: 29 June 2015 - Accepted: 2 July 2015 - Published: 20 July 2015

\begin{abstract}
Ambient volatile organic compounds (VOCs) were measured using an online system, gas chromatographymass spectrometry/flame ionization detector (GC-MS/FID), in Beijing, China, before, during, and after Asia-Pacific Economic Cooperation (APEC) China 2014, when stringent air quality control measures were implemented. Positive matrix factorization (PMF) was applied to identify the major VOC contributing sources and their temporal variations. The secondary organic aerosols potential (SOAP) approach was used to estimate variations of precursor source contributions to SOA formation. The average VOC mixing ratios during the three periods were $86.17,48.28$, and $72.97 \mathrm{ppbv}$, respectively. The mixing ratios of total VOC during the control period were reduced by $44 \%$, and the mixing ratios of acetonitrile, halocarbons, oxygenated VOCs (OVOCs), aromatics, acetylene, alkanes, and alkenes decreased by approximately $65,62,54,53,37,36$, and $23 \%$, respectively. The mixing ratios of all measured VOC species decreased during control, and the most affected species were chlorinated VOCs (chloroethane, 1,1-dichloroethylene, chlorobenzene). PMF analysis indicated eight major sources of ambient VOCs, and emissions from target control sources were clearly reduced during the control period. Compared with the values before control, contributions of vehicular exhaust were most reduced, followed by industrial manufacturing and solvent utilization. Reductions of these three sources were responsible for 50, 26, and $16 \%$ of the reductions in ambient VOCs. Contributions of evaporated or liquid gasoline and industrial chemical feedstock were slightly reduced, and contributions of secondary and long-lived species were relatively stable. Due to central heating, emissions from fuel combus-
\end{abstract}

tion kept on increasing during the whole campaign; because of weak control of liquid petroleum gas (LPG), the highest emissions of LPG occurred in the control period. Vehiclerelated sources were the most important precursor sources likely responsible for the reduction in SOA formation during this campaign.

\section{Introduction}

Beijing, the capital of China, is one of the world's megacities, with a population of more than 20 million and a vehicle fleet of more than 5 million (Beijing Municipal Bureau of Statistics, 2014). High levels of coal consumption, thousands of active construction sites, and rapid increases in vehicles have resulted in high emissions of fine particles $\left(\mathrm{PM}_{2.5}\right)$, sulfur dioxides $\left(\mathrm{SO}_{2}\right)$, nitrogen oxides $\left(\mathrm{NO}_{x}\right)$, and volatile organic compounds (VOCs) in Beijing (Tang et al., 2009; Han et al., 2013; Y. S. Wang et al., 2014).

In November 2014, China hosted the Asia-Pacific Economic Cooperation (APEC) Meeting in Beijing, including the Concluding Senior Officials' Meeting on 5-6 November, the 26th APEC Ministerial Meeting on 7-8 November, and the 22nd APEC Economic Leaders' Meeting on 1011 November. As the host city, Beijing set rigorous plans to reduce emissions of air pollutants in Beijing and neighbouring regions from 1 to 12 November 2014, which resulted in a period of air quality control. The target sources included vehicles, paint and solvent use, steel factories, chemical factories, power plants, etc. A detailed description of the control 
measures is provided in Table $\mathrm{S} 1$ in the Supplement. As a result, air quality was greatly improved, and the phrase "APEC blue" was coined on social media to describe the clear sky. The city's daily $\mathrm{PM}_{2.5}$ concentration during the control period fell to $43 \mu \mathrm{g} \mathrm{m}^{-3}$, a $55 \%$ reduction compared with the same dates the prior year, and daily average levels of $\mathrm{SO}_{2}$, nitrogen dioxide $\left(\mathrm{NO}_{2}\right)$, and $\mathrm{PM}_{10}$ (aerosol particles with an aerodynamic diameter of less than $10 \mu \mathrm{m}$ ) decreased by 57 , 31 and $44 \%$, respectively (Beijing Municipal Environmental Protection Bureau, http://www.bjepb.gov.cn/). However, sufficiently detailed information of ambient VOC mixing ratios and chemical compositions, as well as variations in their sources before, during, and after the control period has not been reported.

Many VOCs adversely affect public health (The Clean Air Act Amendments of 1990, http://www.epa.gov/oar/caa/ caaa_overview.html), and high levels of ambient VOCs have been detected in Beijing, likely associated with rapid economic development. For example, during 1980-2005, VOC emissions increased at an annual average rate of $10.6 \%$ in Beijing (Bo et al., 2008). Ambient VOC measurements during 2002-2003 at six sites in Beijing revealed an average total VOC concentration of $132.6 \pm 52.2 \mu \mathrm{g} \mathrm{m}^{-3}$ with contributions from alkanes (35\%), alkenes (17\%), and aromatics (22\%; Liu et al., 2005). A recent study has shown that non-methane hydrocarbon (NMHC) concentrations in Beijing are more than twice as high as in other cities (M. Wang et al., 2014). Therefore, it is very necessary to formulate a cost-effective policy for reducing VOC emissions in Beijing.

VOCs play an important role in the formation of secondary organic aerosol (SOA) (Johnson et al., 2006; Ran et al., 2011; Zhang et al., 2014). $\mathrm{PM}_{2.5}$ is a key air pollutant in terms of adverse human health effects and visibility degradation (Tao et al., 2014). The severe haze pollution in Beijing was driven to a large extent by secondary aerosol formation, which contributed 30-77 and 44-71\% of $\mathrm{PM}_{2.5}$ and of organic aerosol concentrations, respectively (Huang et al., 2014). Detailed information on VOC characteristics before, during, and after the control period will help future study on SOA formation mechanisms. Assessing VOC source variations will be essential to understanding the effect of abatement measures for VOCs and SOA formation.

To quantitatively assess the contributions of different sources to ambient VOC levels, we can use a combination of direct VOC measurements and receptor models. Receptor models are statistical tools used to identify and quantify sources of ambient air pollution at a given location by analyzing concentration data obtained at a receptor site without emission inventories. Source apportionment tools such as principal component analysis, Unmix, chemical mass balance, and positive matrix factorization (PMF) have been previously developed (Paatero and Tapper, 1994; Watson et al., 2001). The latter is widely used to study VOC source contributions in urban areas because only time series of observed concentrations are used for the input parameters of the PMF

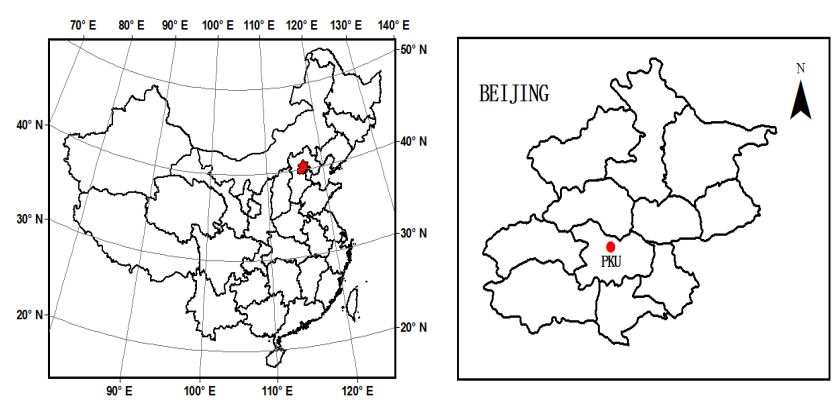

Figure 1. The location of Beijing city in China and the sampling site in Beijing.

calculation, which means that PMF results are not affected by uncertainties in emission profiles (Bon et al., 2011; McCarthy et al., 2013). With PMF, it is also possible to calculate contributions from unknown emission sources. The concept of secondary organic aerosol potential (SOAP) has been developed to reflect the propensity of each organic compound to form SOA on the basis of an equal mass emitted relative to toluene (Derwent et al., 2010). By combining the SOAP scale with contributions from different sources to ambient VOC levels, it has been possible to evaluate the effect of abatement measures for SOA formation.

In this study, we measured 102 VOC species using online instruments at an observatory at Peking University in 2014, from 18 October to 22 November. The hourly mixing ratios and chemical compositions of ambient VOCs before, during and after the control period were investigated. A PMF model was used to extract the VOC sources for this campaign, and comparison of the source contributions before, during and after the control period help to evaluate the effect of the control measures on VOCs. SOAP-weighted mass contributions of each VOC source were used to estimate variations of precursor source contributions to SOA formation.

\section{Methodology}

\subsection{Sampling site}

We sampled on the roof of the technical physics building at Peking University $(\mathrm{PKU})\left(39.99^{\circ} \mathrm{N}, 116.33^{\circ} \mathrm{E}\right), \sim 20 \mathrm{~m}$ above ground. PKU is located in a primarily residential and commercial area in northwestern Beijing (Fig. 1). Local VOC emission sources within $1 \mathrm{~km}$ of PKU include vehicular traffic and fuel combustion for cooking; additionally, a fourth ring road that carries very heavy traffic is located directly south of the site.

Samples were collected at an interval of $1 \mathrm{~h}$ from 18 October to 22 November 2014. To determine the effect of the control plans, we divided the whole study into three parts: before APEC China 2014 (18-31 October), during APEC China 2014 (control period; 3-12 November) and 
after APEC China 2014 (13-22 November). We did not use samples collected on 1 or 2 November because they represented a transition from the non-source control to the control period. The average temperatures before, during, and after the control period were $12.63,7.37$, and $5^{\circ} \mathrm{C}$, respectively. The average wind speeds were $3.86,6.85$, and $5 \mathrm{~m} \mathrm{~s}^{-1}$, respectively. Meteorological data were collected from the NOAA Satellite and Information Service (http://www7.ncdc. noaa.gov/CDO/cdo).

\subsection{Sampling and analysis}

Ambient VOCs were collected and analyzed continuously and automatically using a custom-built online system, GCMS/FID, with a time resolution of $1 \mathrm{~h}$ (TH-PKU 300B, Yuan et al., 2012; Li et al., 2014). The online system combines a sampling system, electronic refrigeration technology, and GC-MS/FID to sample, pre-concentrate, and analyze VOC samples. Moisture and $\mathrm{CO}_{2}$ are removed before VOC analysis. The system uses dual columns and dual detectors to simultaneously analyze C2-C12 VOCs, and the VOC species measured by GC-MS/FID are listed in Table S2 in the Supplement. Most C2-C5 hydrocarbons were separated on a PLOT-A12O 3 column $(15 \mathrm{~m} \times 0.32 \mathrm{~mm}$ ID $\times 3 \mu \mathrm{m}, \mathrm{J} \& \mathrm{~W}$ Scientific, USA), and measured by the FID channel. Other compounds were separated on a semi-polar column (DB$624,60 \mathrm{~m} \times 0.25 \mathrm{~mm}$ ID $\times 1.4 \mu \mathrm{m}, \mathrm{J} \& \mathrm{~W}$ Scientific, USA) and quantified using a quadrupole MS detector.

These chemical analyses were subjected to rigorous quality assurance and quality control procedures. We used an external standard method for the quantification of $\mathrm{C} 2-\mathrm{C} 5$ hydrocarbons, and an internal standard method for MS quantification of VOCs. Four compounds were used as internal standards: bromochloromethane, 1,4-difluorobenzene, chlorobenzene-d5, and bromofluorobenzene. We used two sets of certificated standards, a mixture of 55 NMHCs (provided by Spectra Gases Inc., USA), and a mixture of oxygenated VOCs (OVOCs) and halocarbons (provided by Apel-Riemer Environmental Inc., USA). Five concentrations (0.4-8 ppbv) were used to perform both calibrations. $R^{2}$ values for calibration curves were all above 0.999 and 0.99 for NMHCs and other species, respectively, indicating that integral areas of peaks were proportional to concentrations of target compounds. We performed daily calibrations, and the variations in target species responses were within $\pm 10 \%$ of the calibration curve. The definitions of the method detection limit (MDL) for each compound are given in US Environmental Protection Agency (U.S. EPA) document TO-15, and the MDL of the online GC-MS/FID system for each species ranged from 0.002 to $0.070 \mathrm{ppbv}$ (Yuan et al., 2012). Detailed information of this system can be found in Li et al. (2014).

\subsection{Source apportionment}

The US PMF 5.0 (U.S. EPA, 2014) was applied to identify major VOC sources and their temporal variations. PMF assumes that measured concentrations at receptor sites are linear combinations of contributions from different factors (Paatero and Tapper, 1994). Based on the uncertainties inherent in each observation, the PMF solution minimizes the objective function $Q$, as shown in Eq. (1):

$$
Q=\sum_{i=1}^{m} \sum_{j=1}^{n}\left[\frac{x_{i j-\sum_{k=1}^{p} g_{i k f} j}}{u_{i j}}\right]^{2},
$$

where $u$ is the uncertainty estimate of source $j$, measured in sample $i$.

The detailed calculation method of uncertainty is shown in Reff et al. (2007). The best PMF solution should make the value of $Q$ identical to that of $Q_{\text {theoretical }}$. $Q_{\text {theoretical }}$ can be calculated as Eq. (2):

$Q_{\text {theoretical }}=i \times j-p \times(i+j)$,

where $i$ is the number of samples, $j$ is the number of species, and $p$ is the number of factors.

There is a rotational ambiguity in PMF results, and one way to choose among possible solutions is to use the $F_{\text {peak }}$ parameter. " $F_{\text {peak }}$ " is used to rotate an incorrect solution back to the real solution. The U.S. EPA PMF 5.0 has added two key components to the 3.0 version: two additional error estimation methods and source contribution constraints (U.S. EPA, 2014).

\subsection{Calculation of SOAP-weighted mass contributions of each VOC source}

SOAP-weighted mass contributions of each VOC source were used to estimate variations of precursor source contributions to SOA formation. The SOAP represents the propensity for an organic compound to form SOA when an additional mass emission of that compound is added to the ambient atmosphere expressed relative to that SOA formed when the same mass of toluene is added (Derwent et al., 2010). SOAPs are expressed as an index relative to toluene $=100$. Toluene was chosen as the basic compound for the SOAP scale because its emissions are well characterized and it is widely recognized as an important man-made precursor to SOA formation (Johnson et al., 2006; Kleindienst et al., 2007; $\mathrm{Hu}$ et al., 2008). SOAPs, expressed relative to toluene $=100$, for 100 organic compounds are listed in Table S3, which are derived from Derwent et al. (2010).

We hypothesized that all measured VOC species would have the greatest effect on SOA formation. The SOAPweighted mass contribution of each VOC source can be calculated using Eq. (3):

$\mathrm{SOAP}_{\text {weighted mass contribution }}=\sum\left(\mathrm{VOCs}_{(i)} \times \operatorname{SOAP}_{(i)}\right.$, 
Table 1. Volatile organic compound (VOC) mixing ratios (ppbv), measured in Beijing.

\begin{tabular}{|c|c|c|c|c|c|c|}
\hline \multirow[t]{2}{*}{ VOC groups } & \multicolumn{2}{|c|}{$\operatorname{Before}\left(N^{\mathrm{a}}=240 ; 17-31 \mathrm{Oct}^{\mathrm{b}}\right)$} & \multicolumn{2}{|c|}{$\operatorname{During}(N=234 ; 03-12$ Nov $)$} & \multicolumn{2}{|c|}{$\operatorname{After}(N=221 ; 13-22 \mathrm{Nov})$} \\
\hline & Range & Average \pm sd & Range & Average \pm sd & Range & Average \pm sd \\
\hline Alkanes & $3.39-109.87$ & $32.1 \pm 18.89$ & $2.21-66.48$ & $20.39 \pm 15.45$ & $5.25-90.54$ & $26.57 \pm 19.09$ \\
\hline Alkenes & $0.66-31.05$ & $9.39 \pm 5.42$ & $0.26-25.39$ & $7.22 \pm 6.30$ & $0.92-63.50$ & $14.58 \pm 12.99$ \\
\hline Aromatics & $1.00-46.5$ & $9.55 \pm 5.97$ & $0.46-16.81$ & $4.52 \pm 3.59$ & $0.85-32.75$ & $7.14 \pm 6.30$ \\
\hline Acetylene & $0.36-23.7$ & $6.41 \pm 4.17$ & $0.24-15.24$ & $4.04 \pm 3.34$ & $0.70-32.31$ & $8.27 \pm 7.04$ \\
\hline OVOCs & $4.29-40.49$ & $15.27 \pm 7.08$ & $2.15-20.79$ & $7.09 \pm 3.67$ & $2.70-35.08$ & $9.36 \pm 6.28$ \\
\hline Halocarbons & $4.71-34.14$ & $12.37 \pm 5.28$ & $1.89-14.33$ & $4.64 \pm 2.35$ & $1.84-46.89$ & $6.54 \pm 5.85$ \\
\hline Acetonitrile & $0.20-19.71$ & $1.09 \pm 2.37$ & $0.08-4.35$ & $0.38 \pm 0.40$ & $0.11-1.50$ & $0.49 \pm 0.33$ \\
\hline Total VOCs & $17.05-247.93$ & $86.17 \pm 43.67$ & $9.39-147.95$ & $48.28 \pm 33.87$ & $0.85-271.91$ & $72.97 \pm 55.69$ \\
\hline
\end{tabular}

${ }^{\mathrm{a}}$ Sampling number; ${ }^{\mathrm{b}}$ Sampling date.

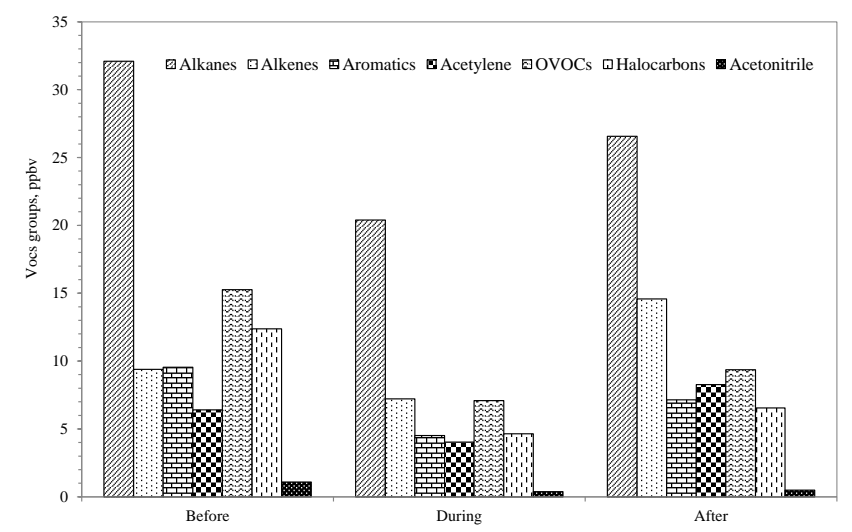

Figure 2. Mixing ratios of volatile organic compound (VOC) groups before, during, and after the control period during APEC China 2014.

where $(\mathrm{VOCs})_{(i)}$ is the mass contribution of a VOC source to species $i\left(\mu \mathrm{g} \mathrm{cm}^{-3}\right)$, estimated by PMF analysis (linking with the molar mass of VOC species and basing on ideal gas law. We convert the unit of VOC species from ppbv to $\mu \mathrm{g} \mathrm{m}^{-3}$ ); $\operatorname{SOAP}_{(i)}$ is the SOA formation potential for species $i$ (unitless, Table S3).

SOA formation is dependent on background environmental conditions, particularly $\mathrm{NO}_{x}$ levels, which make it difficult to accurately quantify absolute SOA emissions. However, because the SOAP approach references the SOA increments to toluene, it removes much of the influence of the uncertainties in the absolute SOA concentrations. Although SOAPs were obtained using highly idealized test conditions, this approach can be used to evaluate the relative contribution of each VOC source to the reduction of SOA during the air quality control period.

\section{Results and discussion}

\subsection{Mixing ratios and chemical speciation}

Ambient VOC mixing ratios and chemical compositions at PKU are summarized in Table 1. Before the control period, the mixing ratios of total VOCs averaged $86.17 \mathrm{ppbv}$ and ranged from 17.05 to 247.93 ppbv. During control, this was reduced to $48.28 \mathrm{ppbv}$, with a range of 9.39-147.95 ppbv. After the control period, the mixing ratios of total VOCs increased to an average of $72.97 \mathrm{ppbv}$. Thus, the mixing ratios of total VOCs were reduced by $43.97 \%$ during the control period compared with the period before control. Compared with the period after control, the mixing ratios were $33.16 \%$ lower during control.

Alkanes were the most abundant VOC group in all three periods, comprising 37, 42 and $36 \%$, respectively. Although lower, the contribution of alkenes increased over time, with this group comprising 11,15 and $20 \%$ of total VOCs before, during, and after the control period, respectively. Compared with the period before control, the mixing ratios of alkanes, alkenes, aromatics, acetylene, OVOCs, halocarbons and acetonitrile decreased by approximately 36, 23, 53, 37, 54, 62, and $65 \%$, respectively, during control (Fig. 2). Notably, acetonitrile, halocarbons, OVOCs and aromatics were reduced by more than $50 \%$. After the control period, alkanes and acetylene increased to the greatest extent, and mixing ratios were twice as high as those during control. The mixing ratios of other VOC groups increased by $\sim 30 \%$ after the control period.

As each source type has its own fingerprint, variations in chemical compositions differed (Wang et al., 2010). The average mixing ratio of the 102 measured species are listed in Table 2. Ethane, ethylene, acetylene, propane and acetone are the five most abundant species during all the three periods. Compared with the period before control, the mixing ratios of all species decreased (Table 3). Tracers of industrial sources decreased most, including some halocarbons and esters. 2,2- 
Table 2. Average mixing ratios (ppbv) of VOC species measured in Beijing.

\begin{tabular}{|c|c|c|c|c|c|c|c|}
\hline Species & Before & During & After & Species & Before & During & After \\
\hline Ethane & 10.80 & 7.71 & 11.31 & Trichloroethylene & 0.14 & 0.07 & 0.08 \\
\hline Propane & 6.38 & 4.44 & 5.40 & 1,2-Dichloropropane & 1.01 & 0.36 & 0.67 \\
\hline Isobutane & 2.32 & 1.57 & 1.75 & Bromodichloromethane & 0.00 & 0.00 & 0.00 \\
\hline$n$-Butane & 3.27 & 1.89 & 2.25 & trans-1,3-Dichloropropene & 0.02 & 0.01 & 0.01 \\
\hline Cyclopentane & 0.35 & 0.09 & 0.14 & cis-1,3-Dichloropropene & 0.01 & 0.00 & 0.00 \\
\hline Isopentane & 2.16 & 1.14 & 1.41 & 1,1,2-Trichloroethane & 0.10 & 0.04 & 0.06 \\
\hline$n$-Pentane & 1.61 & 0.74 & 0.99 & Tetrachloroethylene & 0.17 & 0.08 & 0.09 \\
\hline 2,2-Dimethylbutane & 0.07 & 0.02 & 0.03 & 1,2-Dibromoethane & 0.00 & 0.00 & 0.00 \\
\hline 2,3-Dimethylbutane & 0.25 & 0.14 & 0.18 & Chlorobenzene & 0.05 & 0.01 & 0.02 \\
\hline 2-Methylpentane & 0.73 & 0.44 & 0.54 & Bromoform & 0.00 & 0.00 & 0.00 \\
\hline 3-Methylpentane & 0.49 & 0.25 & 0.27 & 1,1,2,2-Tetrachloroethane & 0.23 & 0.14 & 0.14 \\
\hline$n$-Hexane & 0.93 & 0.66 & 0.62 & 1,3-Dichlorobenzene & 0.00 & 0.00 & 0.00 \\
\hline 2,4-Dimethylpentane & 0.06 & 0.03 & 0.03 & 1,4-Dichlorobenzene & 0.09 & 0.08 & 0.08 \\
\hline Methylcyclopentane & 0.44 & 0.23 & 0.27 & Benzylchloride & 0.00 & 0.00 & 0.00 \\
\hline 2-Methylhexane & 0.20 & 0.09 & 0.12 & 1,2-Dichlorobenzene & 0.00 & 0.00 & 0.00 \\
\hline Cyclohexane & 0.41 & 0.13 & 0.18 & Acrolein & 0.30 & 0.17 & 0.27 \\
\hline 2,3-Dimethylpentane & 0.12 & 0.05 & 0.07 & Propanal & 0.61 & 0.30 & 0.31 \\
\hline 3-Methylhexane & 0.21 & 0.10 & 0.14 & Acetone & 4.29 & 2.19 & 2.48 \\
\hline 2,2,4-Trimethylpentane & 0.18 & 0.09 & 0.11 & Methylacetate & 1.02 & 0.39 & 0.56 \\
\hline$n$-Heptane & 0.26 & 0.12 & 0.18 & MTBE & 0.88 & 0.39 & 0.42 \\
\hline Methylcyclohexane & 0.23 & 0.08 & 0.12 & Methacrolein & 0.06 & 0.02 & 0.05 \\
\hline 2,3,4-Trimethylpentane & 0.09 & 0.04 & 0.05 & Vinylacetate & 0.02 & 0.01 & 0.04 \\
\hline 2-Methylheptane & 0.08 & 0.04 & 0.06 & $n$-Butanal & 0.15 & 0.07 & 0.08 \\
\hline 3-Methylheptane & 0.05 & 0.02 & 0.03 & Methylvinylketone & 0.36 & 0.18 & 0.23 \\
\hline Octane & 0.13 & 0.07 & 0.10 & Methylethylketone & 1.79 & 0.59 & 0.76 \\
\hline$n$-Nonane & 0.10 & 0.05 & 0.08 & Ethylacetate & 2.12 & 0.88 & 1.39 \\
\hline$n$-Decane & 0.10 & 0.06 & 0.07 & 2-Pentanone & 0.07 & 0.03 & 0.04 \\
\hline Udecane & 0.06 & 0.04 & 0.05 & $n$-Pentanal & 0.11 & 0.07 & 0.08 \\
\hline Dodecane & 0.05 & 0.05 & 0.04 & 3-Pentanone & 0.02 & 0.01 & 0.01 \\
\hline Ethylene & 7.18 & 5.51 & 11.23 & Methylmethacrylate & 1.73 & 0.97 & 1.37 \\
\hline Propene & 1.33 & 1.16 & 2.42 & $n$-Hexanal & 0.46 & 0.25 & 0.28 \\
\hline trans-2-Butene & 0.12 & 0.10 & 0.15 & $n$-Butylacetate & 1.28 & 0.57 & 1.00 \\
\hline 1-Butene & 0.35 & 0.22 & 0.42 & Acetylene & 6.41 & 4.04 & 8.27 \\
\hline cis-2-Butene & 0.16 & 0.09 & 0.17 & Acetonitrile & 1.09 & 0.38 & 0.49 \\
\hline trans-2-Pentene & 0.06 & 0.03 & 0.05 & Benzene & 1.98 & 1.02 & 1.87 \\
\hline Isoprene & 0.11 & 0.06 & 0.07 & Toluene & 3.31 & 1.57 & 2.37 \\
\hline cis-2-Pentene & 0.03 & 0.01 & 0.02 & Ethylbenzene & 1.13 & 0.49 & 0.74 \\
\hline 1-Hexene & 0.05 & 0.03 & 0.05 & $m / p$-Xylene & 1.01 & 0.48 & 0.71 \\
\hline Bromomethane & 0.01 & 0.01 & 0.01 & $o$-Xylene & 0.71 & 0.32 & 0.49 \\
\hline Chloroethane & 0.10 & 0.02 & 0.04 & Styrene & 0.24 & 0.11 & 0.21 \\
\hline Freon11(CFCl3) & 3.61 & 0.58 & 0.85 & Isopropylbenzene & 0.05 & 0.02 & 0.03 \\
\hline Freon113(C2F3Cl3) & 0.09 & 0.08 & 0.08 & $n$-Propylbenzene & 0.09 & 0.04 & 0.06 \\
\hline 1,1-Dichloroethylene & 0.01 & 0.00 & 0.00 & 3-Ethyltoluene & 0.25 & 0.10 & 0.16 \\
\hline Dichloromethane & 3.76 & 2.00 & 2.60 & 4-Ethyltoluene & 0.13 & 0.05 & 0.08 \\
\hline 1,1-Dichloroethane & 0.26 & 0.11 & 0.15 & $1,3,5$-Trimethylbenzene & 0.09 & 0.04 & 0.06 \\
\hline cis-1,2-Dichloroethylene & 0.03 & 0.02 & 0.04 & 2-Ethyltoluene & 0.10 & 0.04 & 0.07 \\
\hline Chloroform & 0.93 & 0.42 & 0.62 & $1,2,4$-Trimethylbenzene & 0.29 & 0.13 & 0.19 \\
\hline 1,1,1-Trichloroethane & 0.01 & 0.00 & 0.00 & 1,2,3-Trimethylbenzene & 0.08 & 0.04 & 0.06 \\
\hline Tetrachloromethane & 0.16 & 0.11 & 0.12 & 1,3-Diethylbenzene & 0.02 & 0.01 & 0.01 \\
\hline 1,2-Dichloroethane & 1.58 & 0.49 & 0.87 & 1,4-Diethylbenzene & 0.06 & 0.04 & 0.04 \\
\hline
\end{tabular}




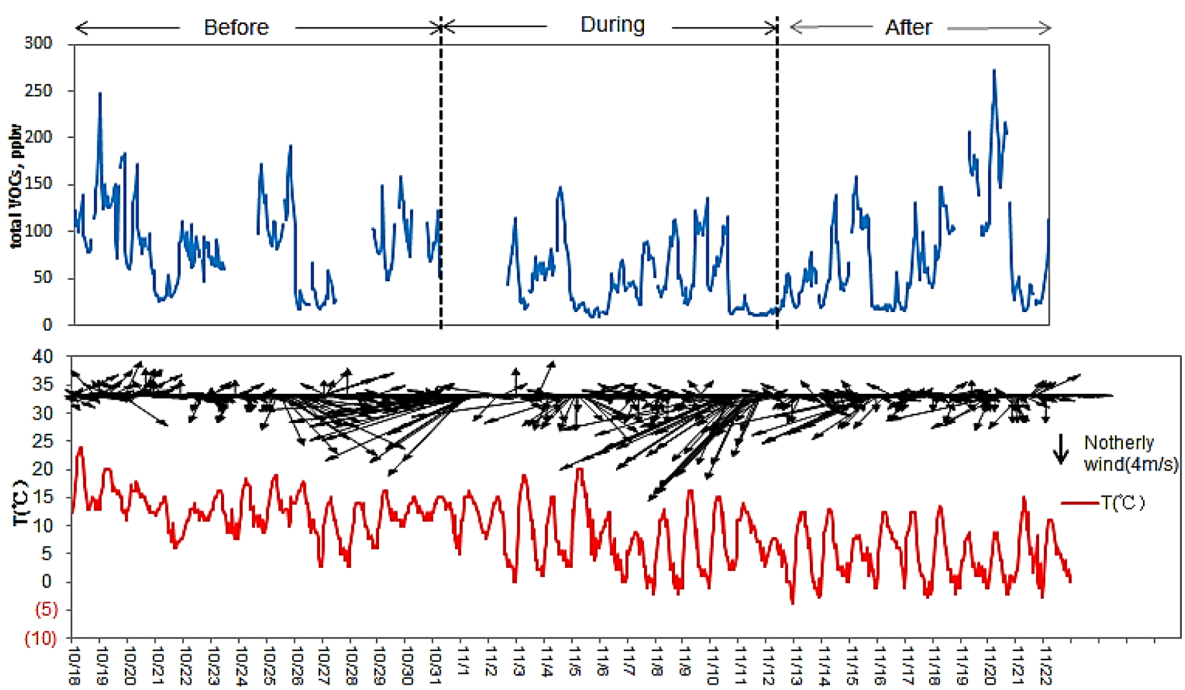

Figure 3. Time series of total measured volatile organic compounds (VOCs), temperature, wind direction, and speed at PKU site during this study.
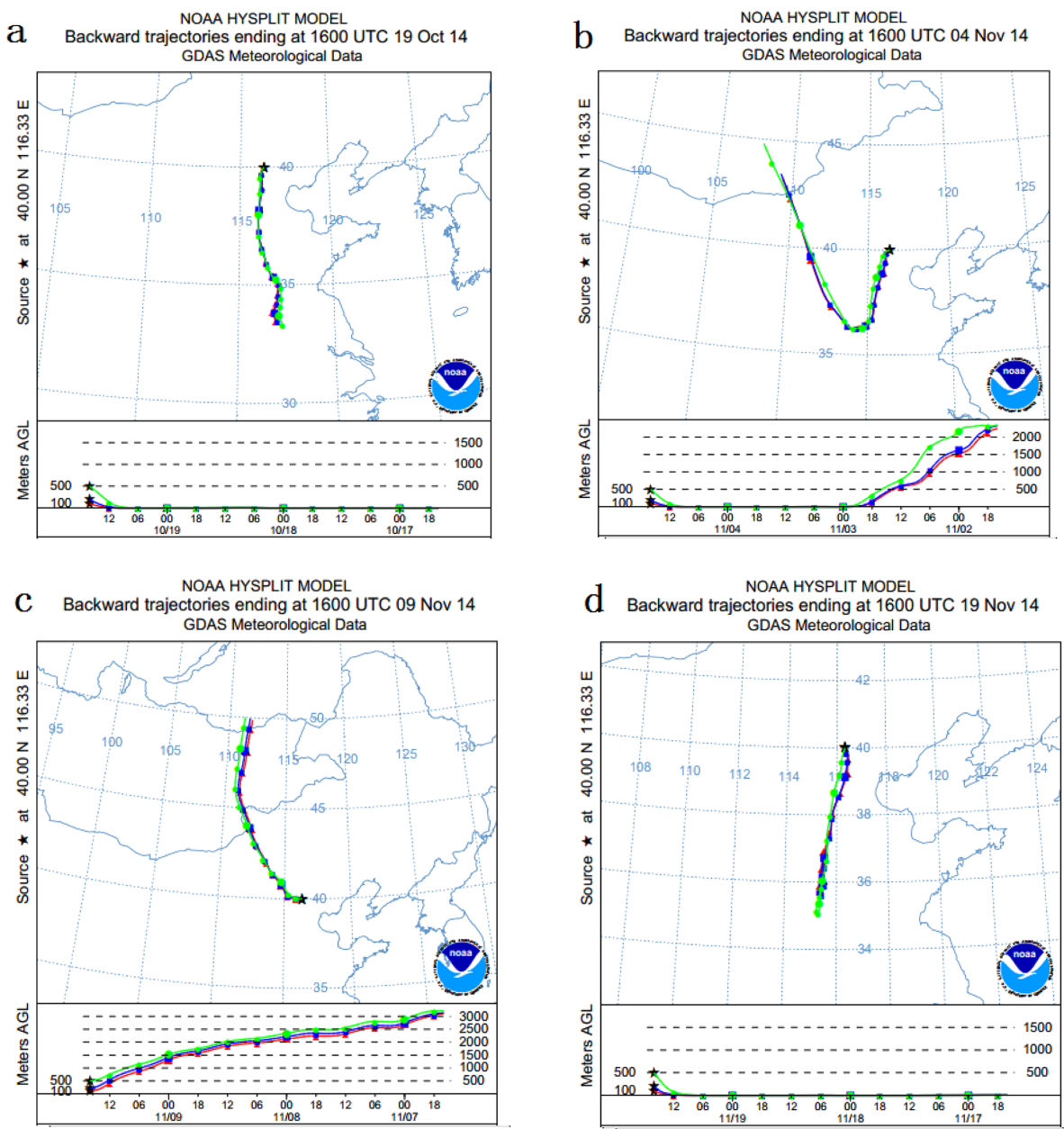

Figure 4. Three-day backward trajectories ending at 12:00 a.m. (16:00 UTC) 19 October, 4, 9, and 19 November 2014. 
Table 3. The top 20 volatile organic compound (VOC) species with the highest decreasing ratios.

\begin{tabular}{lclc}
\hline Species & Decreasing ratio & Species & Decreasing ratio \\
\hline Chloroethane & $80.34 \%$ & 1,2-Dichloropropane & $64.27 \%$ \\
1,1-Dichloroethylene & $76.46 \%$ & Methylcyclohexane & $63.67 \%$ \\
Chlorobenzene & $74.24 \%$ & cis-1,3-Dichloropropene & $62.49 \%$ \\
Cyclopentane & $72.58 \%$ & trans-1,3-Dichloropropene & $62.36 \%$ \\
1,2-Dichloroethane & $69.14 \%$ & Methylacetate & $61.67 \%$ \\
Cyclohexane & $68.13 \%$ & 2,3-Dimethylpentane & $61.23 \%$ \\
Methylethylketone & $66.91 \%$ & Ethylacetate & $58.80 \%$ \\
Methacrolein & $65.12 \%$ & 4-Ethyltoluene & $58.39 \%$ \\
Acetonitrile & $65.12 \%$ & 3-Ethyltoluene & $58.25 \%$ \\
2,2-Dimethylbutane & $64.79 \%$ & 1,1-Dichloroethane & $58.23 \%$ \\
\hline
\end{tabular}

Dimethylbutane, a tracer of motor vehicle exhaust (Chang et al., 2004), was 1 of the top 20 most decreased species.

\subsection{Temporal distribution of ambient VOCs}

Figure 3 displays the time series of total VOCs together with meteorological parameters observed at the PKU site during this campaign. This clearly shows two major pollution episodes, characterized by significantly elevated VOC concentrations. The first occurred during 18-19 October (before control) and the second during 19-20 November (after control). During the first episode, the highest VOC mixing ratios were recorded at midnight on 18 October, when wind speed was relatively low $\left(\sim 2 \mathrm{~ms}^{-1}\right)$, and VOC levels sharply increased from $\sim 80$ to $\sim 250 \mathrm{ppbv}$ within $12 \mathrm{~h}$. During the second episode, the peak VOC mixing ratio was more than $270 \mathrm{ppbv}$, when wind speed was an average of $2 \mathrm{~m} \mathrm{~s}^{-1}$, and VOC levels rose gradually from $\sim 90$ to $\sim 270$ ppbv, perhaps caused by the accumulation of pollutants. During the control period, no heavy pollution occurred, but we found episodes of light pollution with elevated VOC mixing ratios: at midnight on 5 November and during the morning of 10 November. Both had peak values below 150 ppbv, significantly lower than those found before and after the control period.

To investigate pollution origins and transport pathways, 72-h air mass back trajectories arriving at an elevation of 100, 200, and $500 \mathrm{~m}$ were calculated at 12:00 a.m. (16:00 UTC) on 19 October and 4, 9, and 19 November for the PKU site using the NOAA Hybrid Single-Particle Lagrangian Integrated Trajectory (HYSPLIT) model (Fig. 4). This method showed that the air masses on 19 October originated from south China, and passed through Henan and Hebei Provinces, before reaching PKU (Fig. 4a). The air masses on 4 November originated from the northwest part of Inner Mongolia, and passed through Hebei Province, before reaching PKU (Fig. 4b). The air masses on 9 November originated from Mongolia and then passed through Inner Mongolia (Fig. 4c). The air mass on 19 November came from the south, passing through Shandong and Henan provinces (Fig. 4d).
The diurnal variations of ambient NMHCs and OVOCs before, during, and after the control period are shown in Fig. 5. NMHC values for the three periods showed similar daily variations: stable during the night, decreasing after sunrise, at a minimum in the afternoon (14:00-16:00 LT), then increasing at night. This is likely caused by the descending boundary layer and possible night emissions (Li et al., 2014). In the control period, diurnal variations of NMHCs were less clear than those during the other periods, perhaps due to lower night emissions. There were no obvious daily variations in OVOCs. Because of secondary formation during the daytime, photolysis loss, and variation in the boundary layer, ambient OVOC levels were stable (Chen et al., 2014).

During the period after control, nighttime NMHC mixing ratios were much higher than those before control, suggesting that nighttime emission sources may differ. We also found some evidence for the higher nighttime VOC mixing ratios in the period after control. Figure 6 shows the hourly average diurnal profiles for 2,2-dimethylbutane (2,2-DMB) and acetylene before, during, and after the control. 2,2-DMB is considered a typical tracer for vehicular emissions (Chang et al., 2004), and acetylene is a tracer for vehicular and other combustion processes (Baker et al., 2008). Before the control period, the highest-/lowest-value ratios (the highest average hourly mixing ratio of one VOC species divided by the lowest average hourly mixing ratio of this species) of acetylene and 2,2-DMB were very similar with the values of 2.32 and 2.13 , respectively. During control, the highest-/lowest-value ratio of acetylene (3.05) became larger than the value of 2,2DMB (2.13). After control, the highest-/lowest-value ratio of acetylene (4.08) was significantly higher than the value of 2,2-DMB (2.08). The highest-/lowest-value ratios of acetylene increased over time during the three periods, but the values of 2,2-DMB were relatively stable. So the influence from the planetary boundary layer and vehicular emissions on the higher nighttime mixing ratios of acetylene can be eliminated. Coal combustion was found to be an important source for ambient VOCs during winter in Beijing (M. Wang et al., 2013). We speculate that combustion may have been an 

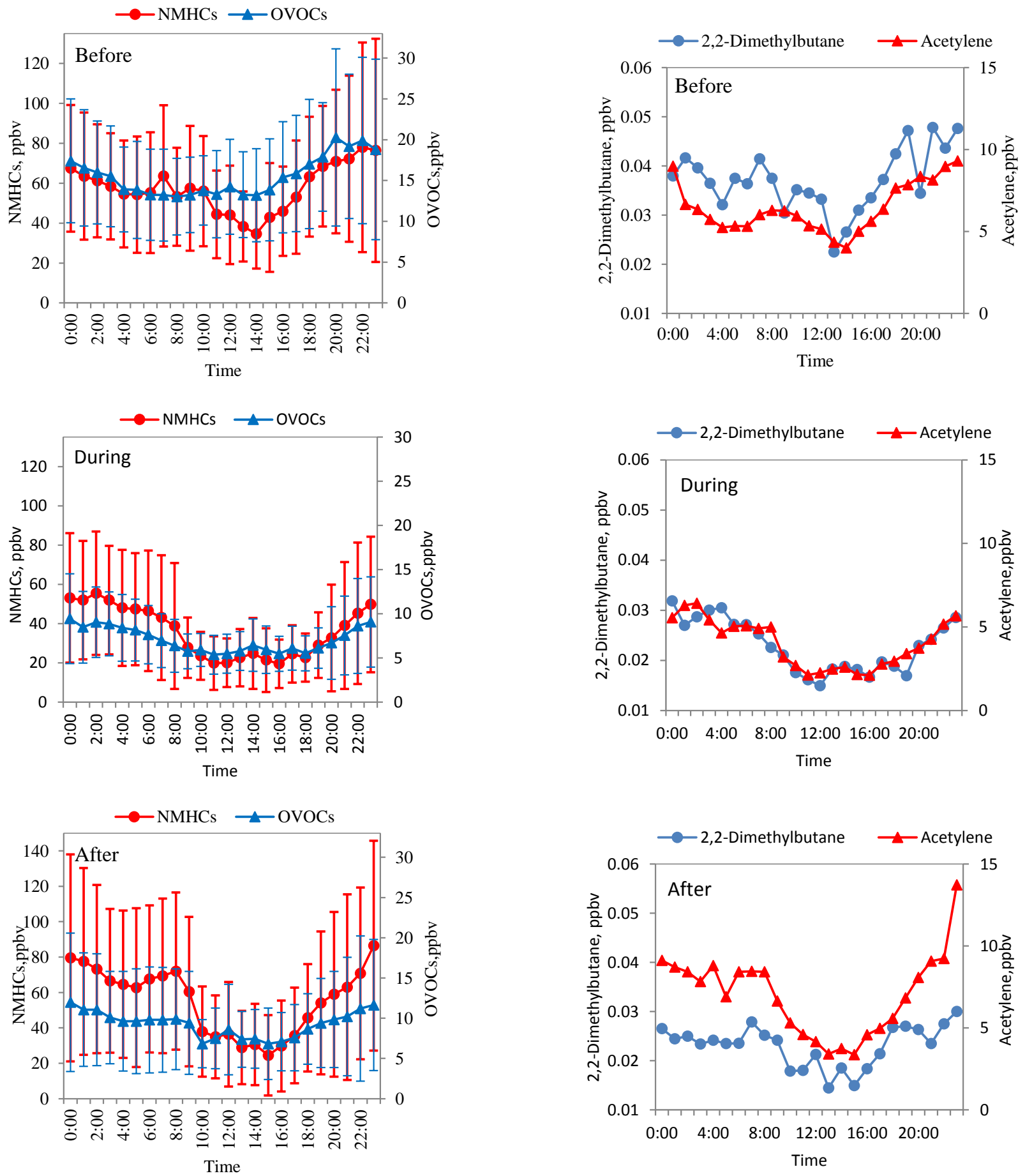

Figure 5. Diurnal variations in mixing ratios of non-methane hydrocarbons (NMHCs) and oxygenated volatile organic compounds (OVOC) at the PKU site before, during, and after the control period during APEC China 2014.

Figure 6. Diurnal variations of mixing ratios of 2,2-dimethylbutane and acetylene at the PKU site before, during, and after the control period during APEC China 2014. 
important nighttime source of VOCs during the second and the third periods.

\subsection{Variations of source emissions}

\subsubsection{Identification of VOC sources}

Source apportionments were performed using a PMF model to calculate reductions in source emissions. We did not use species that were below MDL for more than $50 \%$ of the time or showed a significantly smaller signal to noise ratio $(\mathrm{S} / \mathrm{N})$. An $\mathrm{S} / \mathrm{N}$ ratio was calculated for each species via PMF. After screening, 64 compounds, accounting for $90 \%$ of the total mixing ratios of the 102 VOC species, were used in the PMF analysis; the final data set comprised 695 samples. Modelling was performed for 4-11 factors, and the 8-factor solution was deemed to be most representative.

To attribute PMF factors to emission sources, we compared PMF profiles and reference profiles from the literature. Eight sources were identified: (1) liquid petroleum gas (LPG), (2) industrial manufacturing, (3) industrial chemical feedstock, (4) fuel combustion, (5) solvent utilization, (6) evaporated or liquid gasoline, (7) vehicular exhaust, and (8) secondary and long-lived species. Modelled source profiles together with the relative contributions of individual sources to each analyzed species are shown in Fig. 7.

The first source shown in Fig. 7 is characterized by a significant amount of propane, $i$-butane, and $n$-butane, which are representative species in LPG samples in China ( $\mathrm{Lu}$ et al., 2004). LPG is an important domestic cooking source in Beijing. In 2012, the annual use of LPG was $391200 \mathrm{t}$, of which $340000 t$ were used for cooking. Unlike in other large cities, LPG vehicle use is not widespread in Beijing, and the annual consumption of LPG in the transport sector in 2012 was only $3400 \mathrm{t}$ (China National Bureau of Statistics, 2013). Therefore, this source likely represented emissions from residential LPG consumption, and was identified as "LPG".

Both the second and third sources were industry-related. The second and third source profiles shown in Fig. 7 were characterized by high concentrations of chlorinated VOCs, which are tracers of industries (Scheff and Wadden, 1993; Jiun-Horng et al., 2008). The second source was also characterized by significant amounts of cyclopentane and methylmethacrylate. Cyclopentane is used in the manufacture of synthetic resins and rubber adhesives and as a blowing agent in the manufacture of polyurethane insulating foam; Methylmethacrylate is a transparent thermoplastic and often used as a lightweight or shatter-resistant alternative to soda-lime glass (Nagai, 2001). Therefore, this source was identified as "industrial manufacturing". Key species of the third source profile include chloromethane, chloroform, $n$-hexane and acetone, all of which are widely used as feedstock in organic synthesis (U.S. EPA, 1994). The third source was identified as "industrial chemical feedstock".
The fourth source profile shown in Fig. 7 was associated with over $50 \%$ of the total measured ethylene and acetylene mixing ratios, both of which were major species emitted from combustion process (Liu et al., 2008), and is therefore the believed to be from the combustion process. It was also characterized by significant amounts of ethane, propane, C3-C4 alkenes, and benzene. Ethane is a tracer of natural gas usage, and the source profiles of resident fuel combustion measured in China contained significant alkenes (Q. Wang et al., 2013). Santos et al. (2004) found that coal combustion can release significant amounts of benzene into the atmosphere. Therefore this source is believed to encompass combustion, and may include different fuel types, such as coal, straw and natural gas and was identified as "fuel combustion".

The fifth source profile shown in Fig. 7 was rich in aromatic species (benzene, toluene, ethylbenzene, xylenes, BTEX) and esters (ethylacetate and $n$-butylacetate), and includes a certain amount of halocarbons (1,2-dichloroethane and 1,2-dichloropropane). BTEX is a major constituent of paints (Seila et al., 2001). Esters and halocarbons are used as industrial solvents or adhesives found in paint strippers, varnishes, and furniture (Cai et al., 2010). Thus, this source was considered to be a composite of emissions from solvent use and industrial coatings (Seila et al., 2001). Some major VOC emission sources - such as car manufacturing, printing, furniture manufacturing, shoe making, and toy making are mainly associated with painting and adhesive use and are included in this source category of "solvent utilization".

Both the sixth and seventh source profiles included high mixing ratios of 2,2,4-trimethylpentane and MTBE. 2,2,4Trimethylpentane is a fuel additive used to gain higher octane ratings (McCarthy et al., 2013). MTBE is a common gasoline additive in Beijing (Song et al., 2007). The two sources are both related to vehicle activities. The sources differ in ethane and acetylene mixing ratios, which are higher in the seventh source but are very low in the sixth source. Ethane and acetylene can be formed during the combustion process (Song et al., 2007), so the sixth factor may be an evaporated or liquid gasoline factor and source seven may be a mixture of evaporated or liquid gasoline and vehicular exhaust with rich BTEX, OVOCs, and heavy alkanes, which are tracers of gasoline and diesel exhaust (Liu et al., 2008). This was confirmed by a comparison with typical VOC ratios determined for vehicular exhaust. The mean toluene/benzene ratio of the seventh source profile was 1.50, and Kuster et al. (2004) observe a ratio of 1.59 for vehicular exhaust from several tunnel studies; thus it was identified as "vehicular exhaust".

The eighth source profile, as shown in Fig. 7, is characterized by $52 \%$ of the total Freon 113 mixing ratios, $47 \%$ of the total 1,1,2,2-tetrachloroethane mixing ratios, and $41 \%$ of the total tetrachloromethane mixing ratios. These chemicals have a long lifespan in the atmosphere (McCarthy et al., 2007). The eighth source profile also consists of most carbonyls: acetone, propanal, $n$-pentanal, $n$-butanal and $n$-Hexanal. Considering the abundances of long lifetime compounds and 


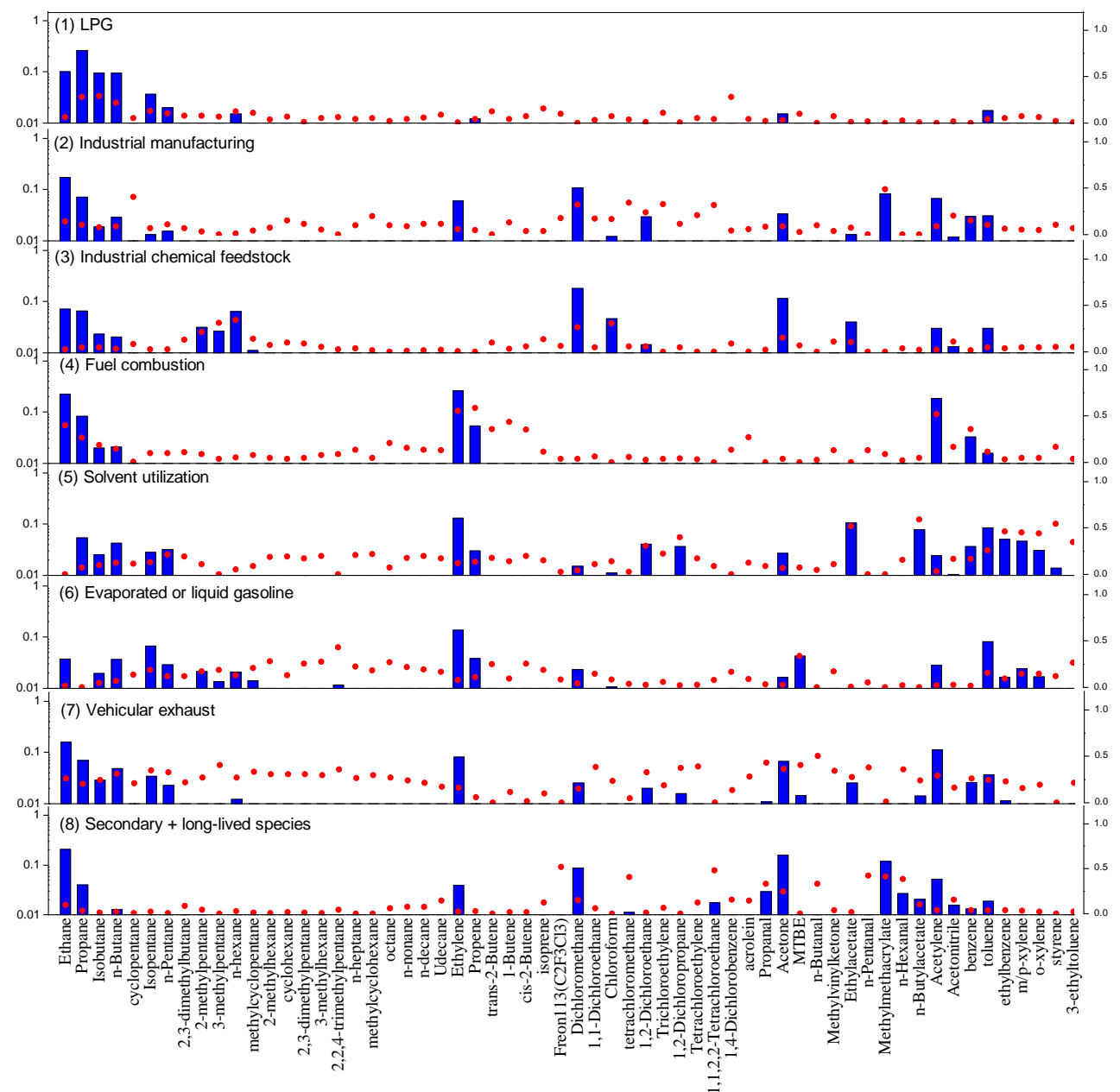

Figure 7. Eight source profiles (bars; $\mathrm{ppbv} \mathrm{ppbv}^{-1}$ ) resolved from PMF model, and contribution percentages (dots) from each source factor.

Table 4. Source contributions (ppbv) derived by PMF analysis.

\begin{tabular}{lrrr}
\hline \multirow{2}{*}{ Source } & \multicolumn{3}{c}{ Average source contribution } \\
\cline { 2 - 4 } & Before & During & After \\
\hline LPG & 6.21 & 7.55 & 3.01 \\
Fuel combustion & 7.05 & 12.70 & 31.77 \\
Industrial manufacturing & 13.51 & 3.22 & 6.10 \\
Industrial chemical feedstock & 4.01 & 3.66 & 3.50 \\
Solvent utilization & 9.68 & 3.48 & 8.05 \\
Evaporated or liquid gasoline & 6.09 & 3.24 & 3.72 \\
Vehicular exhaust & 27.82 & 8.17 & 9.98 \\
Secondary and long-lived species & 4.47 & 5.00 & 4.05 \\
Total & 78.85 & 47.02 & 70.18 \\
\hline
\end{tabular}

carbonyls, we believe that the loadings of VOC species in this source were related to secondary formation and background levels. With a relatively constant contribution, this source was identified as "secondary and long-lived species".

\subsubsection{Estimation of source contributions}

The hourly mixing ratio contributions of each VOC source are presented in Fig. 8. Compared with the non-control periods, the reconstructed mixing ratios of most sources were lower during the control period, including those of industrial manufacturing, industrial chemical feedstock, solvent utilization, evaporated or liquid gasoline, and vehicular exhaust. In contrast, the mixing ratio contributions of LPG showed higher values during the control period. The contributions of fuel combustion increased continuously over time, and the contributions of secondary and long-lived species were relatively constant.

Figure 9 illustrates source contribution percentages before, during and after control, and Table 4 lists the source mixing ratio contributions during the three periods. Before control, vehicular exhaust was the largest contributor $(35 \%)$ to VOC mixing ratios, contributing $27.82 \mathrm{ppbv}$, followed by industrial manufacturing $(13.51 \mathrm{ppbv}, 17 \%)$ and solvent utilization $(9.68 \mathrm{ppbv}, 12 \%)$. Fuel combustion, LPG, evaporated or 


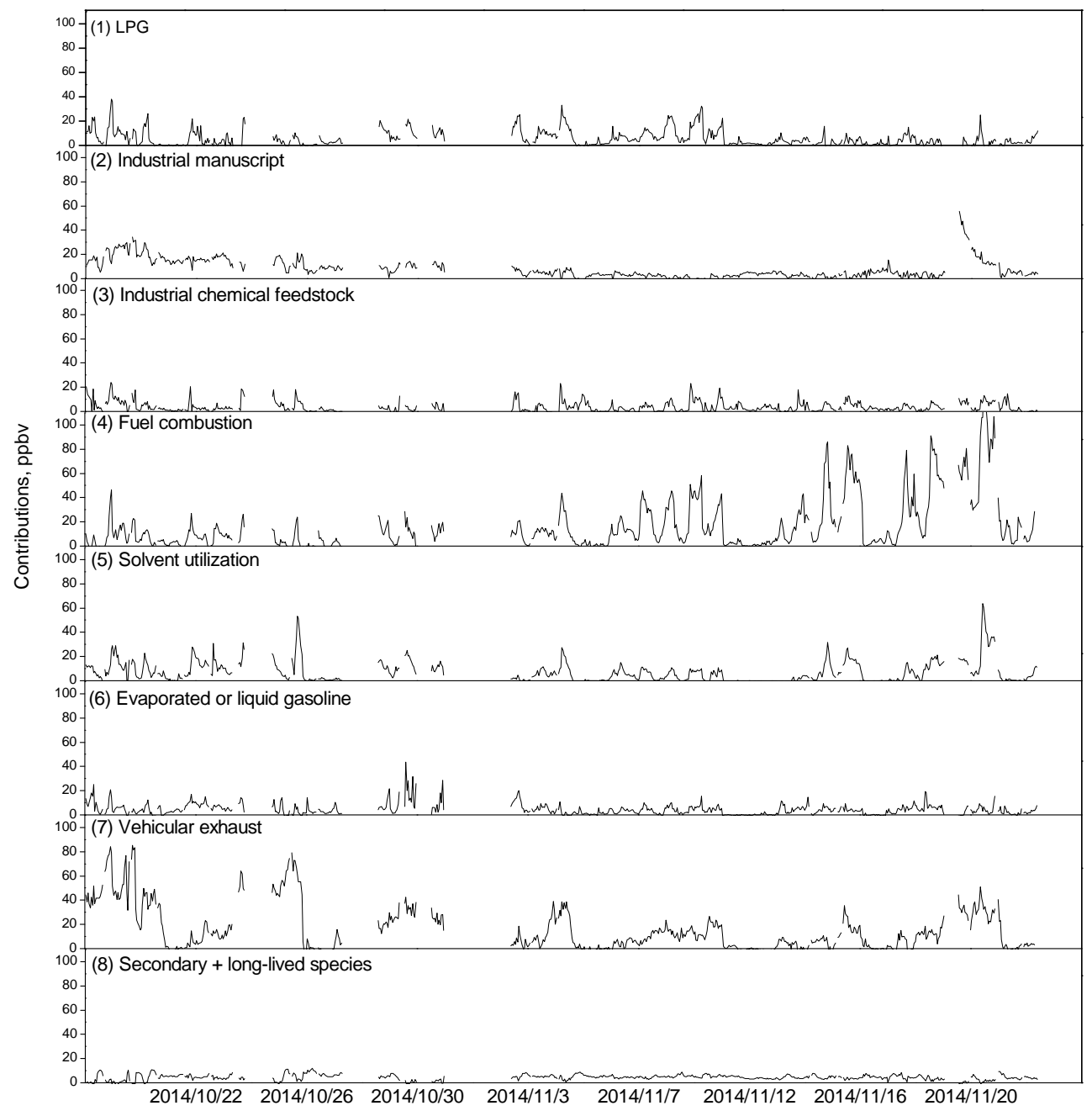

Figure 8. Time series of hourly contributions from each identified source from 18 October to 22 November 2014.

liquid gasoline, secondary and long-lived species, and industrial chemical feedstock contributed $7.05,6.21,6.09,4.47$, and $4.01 \mathrm{ppbv}$, accounting for $9,8,8,6$, and $5 \%$ of the total VOC mixing ratios, respectively. The vehicle-related emission sources, (vehicle exhaust and evaporated or liquid gasoline) together accounted for $43 \%$ of the VOC mixing ratios. The industrial-related emissions, (industrial manufacturing and chemical feedstock) together accounted for $22 \%$ of the VOC mixing ratios. This indicated that traffic and industry sources were major VOC sources before the control period.

During the control period, the largest contributor was fuel combustion, with $12.70 \mathrm{ppbv}$, accounting for $27 \%$ of total VOCs. The second largest contributor was vehicular exhaust, with $8.17 \mathrm{ppbv}$, accounting for $17 \%$ of total VOCs. Contributions from LPG and secondary and long-lived species were 7.55 and $5.00 \mathrm{ppbv}$, respectively. Contributions from industrial chemical feedstock, solvent utilization and evaporated or liquid gasoline were $3.66,3.48$, and $3.24 \mathrm{ppbv}$, accounting for 8,7 , and $7 \%$ of total VOCs, respectively. The con- tribution from industrial manufacturing was relatively low, at 3.22 ppbv.

After control, the city turns to the central heating period and the largest contributor was fuel combustion, with $31.77 \mathrm{ppbv}$, accounting for $45 \%$ of total VOCs. Vehicular exhaust, solvent utilization, industrial manufacturing, secondary and long-lived species, evaporated or liquid gasoline, industrial chemical feedstock and LPG contributed 9.98, 8.05, 6.10, 4.05, 3.72, 3.50, and 3.01 ppbv, accounting for 14, $11,9,6,5,5$, and $4 \%$ of total VOCs, respectively.

Compared with the period before the control, the contributions of vehicular exhaust during the control were reduced to the greatest extent, with a value of $19.65 \mathrm{ppbv}$, followed by industrial manufacturing (10.29 ppbv) and solvent utilization (6.20 ppbv). Evaporated or liquid gasoline and industrial chemical feedstock were slightly reduced, with the values of 2.85 and 0.35 ppbv. Reductions of vehicular exhaust, industrial manufacturing, solvent utilization, evaporated or liquid gasoline, and industrial chemical feedstock 


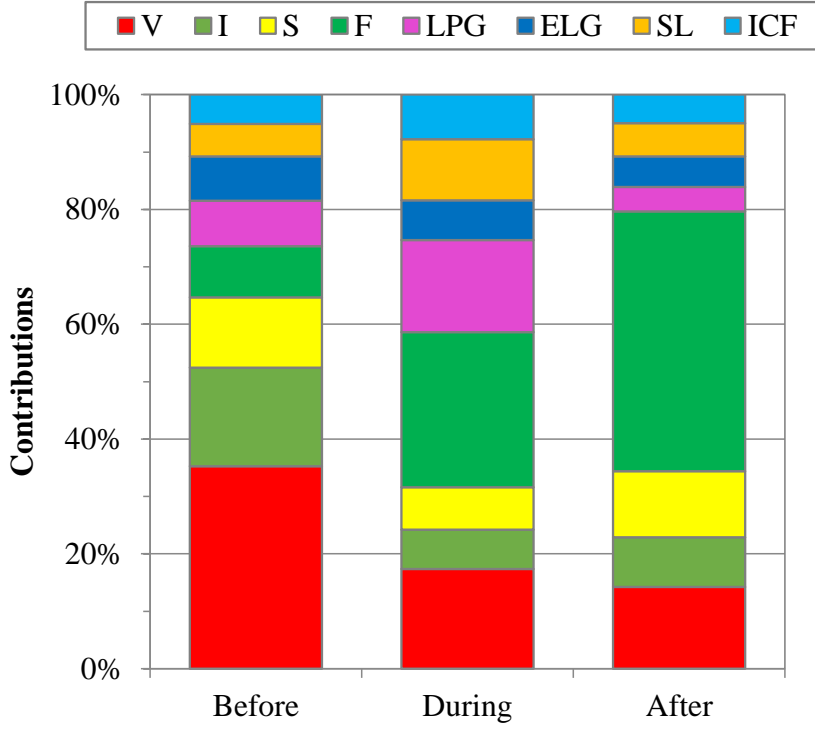

Figure 9. Overall contributions (\%) for the eight sources identified by PMF analysis before, during, and after the control period during the APEC China 2014. "V" stands for vehicular exhaust; "I" stands for Industrial manufacturing; "S" stands for Solvent utilization; "F" stands for fuel combustion; "LPG" stands for liquid petroleum gas; "ELG" stands for evaporated or liquid gasoline; "SL" stands for secondary and long-lived species; "ICF" stands for industrial chemical feedstock.

were responsible for $50,26,16,7$, and $1 \%$ of the reductions in ambient VOCs, indicating that the control measures on traffic were most effective. The contributions of secondary and long-lived species were relatively stable. In contrast, due to central heating and weak control on fuel combustion and LPG, contributions from these sources were elevated by 80 and $22 \%$, respectively. November is a transition month for central heating in northern China, which means that fuel combustion contributions would increase with time. Because of a lack of relative control measures for LPG, the peak contribution of this source occurred during the control period. The temperature difference during this campaign is relatively low, the influence from meteorological variability on VOC evaporation were not considered in this study.

\subsection{Precursor source contributions to SOA}

It is reported that during control the concentration of $\mathrm{PM}_{2.5}$ reduced a lot (Beijing Municipal Environmental Protection Bureau, http://www.bjepb.gov.cn/). SOA constitute a significant fraction of $\mathrm{PM}_{2.5}$ in China (Ding et al., 2012; Guo et al., 2012; Huang et al., 2014) and VOCs play an important role in the formation of SOA. The large reduction of VOCs may lead to the reduction of SOA and contribute to the $\mathrm{PM}_{2.5}$ reduction. SOAP-weighted mass contributions of each VOC source were used to estimate the influence of variations of precursor emissions on SOA. The SOAP-weighted mass con-
Table 5. SOAP-weighted mass contributions $\left(\mu \mathrm{g} \mathrm{cm}^{-3}\right)$ of each VOC source before, during, and after the control period during APEC China 2014.

\begin{tabular}{lrrr}
\hline \multirow{2}{*}{ Source } & \multicolumn{3}{c}{ Source contribution } \\
\cline { 2 - 4 } & Before & During & After \\
\hline LPG & 143 & 174 & 69 \\
Fuel combustion & 158 & 285 & 711 \\
Industrial manufacturing & 494 & 118 & 223 \\
Industrial chemical feedstock & 131 & 120 & 114 \\
Solvent utilization & 1132 & 407 & 941 \\
Evaporated or liquid gasoline & 526 & 280 & 321 \\
Vehicular exhaust & 1087 & 320 & 390 \\
Secondary and long-lived species & 89 & 99 & 80 \\
\hline
\end{tabular}

tributions of each VOC source before, during, and after the control period are listed in Table 5 .

Before the control period, the SOAP-weighted mass contribution of vehicular-related sources was much higher than other VOC source with a value of $1613 \mu \mathrm{g} \mathrm{cm}^{-3}$, accounting for $43 \%$ of the total. In contract, the SOAP-weighted mass contribution of each VOC source was very similar during the control period. Because of the abatement measures for pollutant emissions during the control period, the SOAP-weighted mass contributions of vehicular-related sources were most reduced compared with the period before control, with the value of $1013 \mu \mathrm{g} \mathrm{cm}^{-3}$, explaining the $52 \%$ reduction in SOA.

Solvent utilization was the second largest source of man-made SOA precursors before control with the SOAPweighted mass contributions of $1132 \mu \mathrm{g} \mathrm{cm}^{-3}$, accounting for $43 \%$ of the total. During the control period, the reduction in SOAP-weighted mass contributions from solvent utilization was $725 \mu \mathrm{g} \mathrm{cm}^{-3}$, explaining the $37 \%$ reduction in SOA. The reductions in other VOC sources were much smaller. Thus, vehicle and solvent utilization controls were the most important measures taken to reduce SOA during APEC Chain 2014 in Beijing.

Current knowledge about formation mechanisms of SOA is still very limited (Guo et al., 2012). We have to point out that the SOAP is computed to understand the potential to form SOA for VOC species, which cannot estimate the SOA formation from VOCs actually in certain atmospheric conditions. In this study, we used SOAP approach to discuss the effectiveness of the air quality controls. Detailed VOC data in this work will provide useful information for further study on the formation mechanisms of SOA.

\section{Conclusions}

Mixing ratios of $\mathrm{C} 2-\mathrm{C} 12$ VOCs were measured at an urban site in Beijing before, during and after the APEC China 2014. Total VOC mixing ratios were reduced by $44 \%$ during the 
control period, and the mixing ratios of acetonitrile, halocarbons, OVOCs, aromatics, acetylene, alkanes, and alkenes decreased by approximately $65,62,54,53,37,36$, and $23 \%$, respectively. The mixing ratios of all 102 measured species decreased, with that of chloroethane decreasing the most substantially. PMF analysis shows that contributions from controlled sources, i.e. vehicle-related sources, industrial manufacturing, and solvent utilization, were significantly reduced under air quality regulations. Among these, controls on vehicles were most effective, causing more than half of the reductions in ambient VOCs, and resulting in significant decreases in SOA. Industrial manufacturing controls were the second most important cause of ambient VOC reductions; control on solvent utilization appears to be the second important cause of SOA reductions. Fuel combustion was found to be an important source of ambient VOCs during the central heating period in Beijing.

Our results indicate that the stringent air quality restrictions implemented during APEC China 2014 were successful, and that controls on vehicles were the most important measures to ambient VOCs. As severe haze pollution events in China are mainly driven by secondary aerosol formation, these findings will also provide cost-effective solutions for lessening fine particle pollution. The detailed VOC provided here will provide information for further studies on the SOA formation and human health.

\section{The Supplement related to this article is available online at doi:10.5194/acp-15-7945-2015-supplement.}

Acknowledgements. We appreciate financial support from the Environmental Protection Ministry of China for Research of Characteristics and Controlling Measures of VOC Emissions from Typical Anthropogenic Sources (no. 2011467003) and Research of emission reduction and regulatory system of VOCs in key sectors (no. 20130973).

Edited by: J. Huang

\section{References}

Baker, A. K., Beyersdorf, A. J., Doezema, L. A., Katzenstein, A., Meinardi, S., Simpson, I. J., Blake, D. R., and Rowland, F. S.: Measurements of nonmethane hydrocarbons in 28 United States cities, Atmos. Environ., 42, 170-182, doi:10.1016/j.atmosenv.2007.09.007, 2008.

Beijing Municipal Bureau of Statistics: Beijing Statistical Yearbook 2013 [M], China Statistics Press, Beijing, 2014.

Bo, Y., Cai, H., and Xie, S. D.: Spatial and temporal variation of historical anthropogenic NMVOCs emission inventories in China, Atmos. Chem. Phys., 8, 7297-7316, doi:10.5194/acp-8-72972008, 2008.
Bon, D. M., Ulbrich, I. M., de Gouw, J. A., Warneke, C., Kuster, W. C., Alexander, M. L., Baker, A., Beyersdorf, A. J., Blake, D., Fall, R., Jimenez, J. L., Herndon, S. C., Huey, L. G., Knighton, W. B., Ortega, J., Springston, S., and Vargas, O.: Measurements of volatile organic compounds at a suburban ground site (T1) in Mexico City during the MILAGRO 2006 campaign: measurement comparison, emission ratios, and source attribution, Atmos. Chem. Phys., 11, 2399-2421, doi:10.5194/acp-11-23992011, 2011.

Cai, C. J., Geng, F. H., Tie, X. X., Yu, Q. O., and An, J. L.: Characteristics and source apportionment of VOCs measured in Shanghai, China, Atmos. Environ., 44, 5005-5014, doi:10.1016/j.atmosenv.2010.07.059, 2010.

Chang, C. C., Chen, T. Y., Chou, C., and Liu, S. C.: Assessment of traffic contribution to hydrocarbons using 2,2-dimethylbutane as a vehicular indicator, Terr. Atmos. Ocean. Sci., 15, 697-711, 2004.

Chen, W. T., Shao, M., Lu, S. H., Wang, M., Zeng, L. M., Yuan, B., and Liu, Y.: Understanding primary and secondary sources of ambient carbonyl compounds in Beijing using the PMF model, Atmos. Chem. Phys., 14, 3047-3062, doi:10.5194/acp-14-30472014, 2014.

China National Bureau of Statistics: China Energy Statistical Yearbooks [M], China Statistics Press, Beijing, 2013.

Derwent, R. G., Jenkin, M. E., Utembe, S. R., Shallcross, D. E., Murrells, T. P., and Passant, N. R.: Secondary organic aerosol formation from a large number of reactive man-made organic compounds, Sci. Total. Environ., 408, 3374-3381, doi:10.1016/j.scitotenv.2010.04.013, 2010.

Ding, X., Wang, X.-M., Gao, B., Fu, X.-X., He, Q.-F., Zhao, X.-Y., Yu, J.-Z., and Zheng, M.: Tracer-based estimation of secondary organic carbon in the Pearl River Delta, south China [J], J. Geophys. Res.-Atmos., 117, D05313, doi:10.1029/2011JD016596, 2012.

Guo, S., Hu, M., Guo, Q., Zhang, X., Zheng, M., Zheng, J., Chang, C. C., Schauer, J. J., and Zhang, R.: Primary Sources and Secondary Formation of Organic Aerosols in Beijing, China, Environ. Sci. Technol., 46, 9846-9853, doi:10.1021/es20425641, 2012.

Han, X., Zhang, M. G., Tao, J. H., Wang, L. L., Gao, J., Wang, S. L., and Chai, F. H.: Modeling aerosol impacts on atmospheric visibility in Beijing with RAMS-CMAQ, Atmos. Environ., 72, 177-191, doi:10.1016/j.atmosenv.2013.02.030, 2013.

Hu, D., Bian, Q., Li, T. W. Y., Lau, A. K. H., and Yu, J. Z.: Contributions of isoprene, monoterpenes, beta-caryophyllene, and toluene to secondary organic aerosols in Hong Kong during the summer of 2006, J. Geophys. Res.-Atmos., 113, D22206, doi:10.1029/2008jd010437, 2008.

Huang, R. J., Zhang, Y. L., Bozzetti, C., Ho, K. F., Cao, J. J., Han, Y. M., Daellenbach, K. R., Slowik, J. G., Platt, S. M., Canonaco, F., Zotter, P., Wolf, R., Pieber, S. M., Bruns, E. A., Crippa, M., Ciarelli, G., Piazzalunga, A., Schwikowski, M., Abbaszade, G., Schnelle-Kreis, J., Zimmermann, R., An, Z. S., Szidat, S., Baltensperger, U., El Haddad, I., and Prevot, A. S. H.: High secondary aerosol contribution to particulate pollution during haze events in China, Nature, 514, 218-222, 10.1038/nature13774, 2014.

Jiun-Horng, T., Kuo-Hsiung, L., Chih-Yu, C., Nina, L., Sen-Yi, M., and Hung-Lung, C.: Volatile organic compound constituents 
from an integrated iron and steel facility, J. Health Econ., 157, 569-578, doi:10.1016/j.jhazmat.2008.01.022, 2008.

Johnson, D., Utembe, S. R., and Jenkin, M. E.: Simulating the detailed chemical composition of secondary organic aerosol formed on a regional scale during the TORCH 2003 campaign in the southern UK, Atmos. Chem. Phys., 6, 419-431, doi:10.5194/acp-6-419-2006, 2006.

Kleindienst, T. E., Jaoui, M., Lewandowski, M., Offenberg, J. H., Lewis, C. W., Bhave, P. V., and Edney, E. O.: Estimates of the contributions of biogenic and anthropogenic hydrocarbons to secondary organic aerosol at a southeastern US location, Atmos. Environ., 41, 8288-8300, doi:10.1016/j.atmosenv.2007.06.045, 2007.

Kuster, W. C., Jobson, B. T., Karl, T., Riemer, D., Apel, E., Goldan, P. D., and Fehsenfeld, F. C.: Intercomparison of volatile organic carbon measurement techniques and data at la porte during the TexAQS2000 Air Quality Study, Environ. Sci. Technol., 38, 221228, doi:10.1021/es034710r, 2004.

Li, L. Y., Chen, Y., Zeng, L. M., Shao, M., Xie, S. D., Chen, W. T., Lu, S. H., Wu, Y. S., and Cao, W.: Biomass burning contribution to ambient volatile organic compounds (VOCs) in the ChengduChongqing Region (CCR), China, Atmos. Environ., 99, 403410, doi:10.1016/j.atmosenv.2014.09.067, 2014.

Liu, Y., Shao, M., Zhang, J., Fu, L. L., and Lu, S. H.: Distributions and source apportionment of ambient volatile organic compounds in Beijing city, China, J. Environ. Sci. Health Part A-Toxic/Hazard. Subst. Environ. Eng., 40, 1843-1860, doi:10.1080/10934520500182842, 2005.

Liu, Y., Shao, M., Fu, L. L., Lu, S. H., Zeng, L. M., and Tang, D. G.: Source profiles of volatile organic compounds (VOCs) measured in China: Part I, Atmos. Environ., 42, 6247-6260, doi:10.1016/j.atmosenv.2008.01.070, 2008.

Lu, S. H.: Source apportionment of anthropogenic emissions of volatileorganic compounds, MSc thesis, 43-44, Peking University, 2004.

McCarthy, M. C., Hafner, H. R., Chinkin, L. R., and Charrier, J. G.: Temporal variability of selected air toxics in the United States, Atmos. Environ., 41, 7180-7194, doi:10.1016/j.atmosenv.2007.05.037, 2007.

McCarthy, M. C., Aklilu, Y. A., Brown, S. G., and Lyder, D. A.: Source apportionment of volatile organic compounds measured in Edmonton, Alberta, Atmos. Environ., 81, 504-516, doi:10.1016/j.atmosenv.2013.09.016, 2013.

Nagai, K.: New developments in the production of methyl methacrylate, Appl. Catal. A-Gen., 221, 367-377, doi:10.1016/s0926-860x(01)00810-9, 2001.

Paatero, P. and Tapper, U.: Postive matrix factorization a nonnegative factor model with optimal utilization of error estimates of data values, Environmetrics, 5, 111-126, doi:10.1002/env.3170050203, 1994.

Ran, L., Zhao, C. S., Xu, W. Y., Lu, X. Q., Han, M., Lin, W. L., Yan, P., Xu, X. B., Deng, Z. Z., Ma, N., Liu, P. F., Yu, J., Liang, W. D., and Chen, L. L.: VOC reactivity and its effect on ozone production during the HaChi summer campaign, Atmos. Chem. Phys., 11, 4657-4667, doi:10.5194/acp-11-4657-2011, 2011.

Reff, A., Eberly, S. I., and Bhave, P. V.: Receptor modeling of ambient particulate matter data using positive matrix factorization: Review of existing methods, J. Air. Waste. Manage., 57, 146$154,2007$.
Santos, C. Y. M., Azevedo, D. D., and Aquino Neto, F. R.: Atmospheric distribution of organic compounds from urban areas near a coal-fired power station, Atmos. Environ., 38, 1247-1257, doi:10.1016/j.atmosenv.2003.11.026, 2004.

Scheff, P. A. and Wadden, R. A.: Receptor modeling of volatile organic compounds .1. Emission inventory and validation, Environ Sci. Technol., 27, 617-625, doi:10.1021/es00041a005, 1993.

Seila, R. L., Main, H. H., Arriaga, J. L., Martinez, G., and Ramadan, A.: Atmospheric volatile organic compound measurements during the 1996 Paso del Norte Ozone Study, Sci. Total. Environ., 276, 153-169, doi:10.1016/s0048-9697(01)00777-x, 2001.

Song, Y., Shao, M., Liu, Y., Lu, S. H., Kuster, W., Goldan, P., and Xie, S. D.: Source apportionment of ambient volatile organic compounds in Beijing, Environ. Sci. Technol., 41, 4348-4353, doi:10.1021/es0625982, 2007.

Tang, G., Li, X., Wang, Y., Xin, J., and Ren, X.: Surface ozone trend details and interpretations in Beijing, 2001-2006, Atmos. Chem. Phys., 9, 8813-8823, doi:10.5194/acp-9-8813-2009, 2009.

Tao, J., Gao, J., Zhang, L., Zhang, R., Che, H., Zhang, Z., Lin, Z., Jing, J., Cao, J., and Hsu, S.-C.: $\mathrm{PM}_{2.5}$ pollution in a megacity of southwest China: source apportionment and implication, Atmos. Chem. Phys., 14, 8679-8699, doi:10.5194/acp-14-86792014, 2014.

U.S. EPA: Locating and Estimating Documents, Office of Air Quality Planning and Standards U.S. Environmental Protection Agency, Research Triangle Park, North Carolina, 1994.

U.S. EPA: EPA positive matrix factorization (PMF) 5.0 fundamentals and user guide, US Environmental Protection Agency, Office of Research and Development, Washington, D.C., 2014.

Wang, B., Shao, M., Lu, S. H., Yuan, B., Zhao, Y., Wang, M., Zhang, S. Q., and Wu, D.: Variation of ambient non-methane hydrocarbons in Beijing city in summer 2008, Atmos. Chem. Phys., 10, 5911-5923, doi:10.5194/acp-10-5911-2010, 2010.

Wang, M., Shao, M., Lu, S.-H., Yang, Y.-D., and Chen, W.-T.: Evidence of coal combustion contribution to ambient VOCs during winter in Beijing, Chin. Chem. Lett., 24, 829-832, doi:10.1016/j.cclet.2013.05.029, 2013.

Wang, M., Shao, M., Chen, W., Yuan, B., Lu, S., Zhang, Q., Zeng, L., and Wang, Q.: A temporally and spatially resolved validation of emission inventories by measurements of ambient volatile organic compounds in Beijing, China, Atmos. Chem. Phys., 14, 5871-5891, doi:10.5194/acp-14-5871-2014, 2014.

Wang, Q., Geng, C. M., Lu, S. H., Chen, W. T., and Shao, M.: Emission factors of gaseous carbonaceous species from residential combustion of coal and crop residue briquettes, Front. Env. Sci. Eng., 7, 66-76, doi:10.1007/s11783-012-0428-5, 2013.

Wang, Y. S., Yao, L., Wang, L. L., Liu, Z. R., Ji, D. S., Tang, G. Q., Zhang, J. K., Sun, Y., Hu, B., and Xin, J. Y.: Mechanism for the formation of the January 2013 heavy haze pollution episode over central and eastern China, Sci. China-Earth Sci., 57, 14-25, doi:10.1007/s11430-013-4773-4, 2014.

Watson, J. G., Chow, J. C., and Fujita, E. M.: Review of volatile organic compound source apportionment by chemical mass balance, Atmos. Environ., 35, 1567-1584, doi:10.1016/s13522310(00)00461-1, 2001.

Yuan, B., Shao, M., de Gouw, J., Parrish, D. D., Lu, S. H., Wang, M., Zeng, L. M., Zhang, Q., Song, Y., Zhang, J. B., and Hu, M.: Volatile organic compounds (VOCs) in urban air: How chemistry affects the interpretation of positive matrix factoriza- 
tion (PMF) analysis, J. Geophys. Res.-Atmos., 117, D24302, doi:10.1029/2012jd018236, 2012.
Zhang, Q., Yuan, B., Shao, M., Wang, X., Lu, S., Lu, K., Wang, M., Chen, L., Chang, C.-C., and Liu, S. C.: Variations of ground-level $\mathrm{O}_{3}$ and its precursors in Beijing in summertime between 2005 and 2011, Atmos. Chem. Phys., 14, 6089-6101, doi:10.5194/acp-14-6089-2014, 2014. 